THURSDAY, FEBRUARY I0, I870

\section{THE ROYAL COMMISSION ON SCIENCE}

THE Council of the British Association for the Advancement of Science was received on Friday last by Earl de Grey, Lord President of the Council, as a deputation to urge on the Government the issuing of a Royal Commission to inquire into the state of Science in England.

That such a body, representing as it does, not only the science but the intellect of the nation, more fully than, perhaps, any other association in the kingdom, should take so decided a step is sufficient proof that in the judgment of those best qualified to guide public opinion on the subject, our scientific system. needs reform.

The-truth is that we have no scientific system, properly so called. Nothing can be more distinct than Prof. Stokes's statement to Earl de Grey as to the incompleteness of our arrangements. We have it on his authority that a certain class of Astronomical observations is carried on at the Royal Observatory and that natural objects are displayed at the British Museum; but that experimental research receives "little or no support" from the State. It is not easy to frame a plausible distinction between these branches of science, which shall justify support in one case and neglect in the other. The existing anomaly may be explained by the facts that astronomy and natural history have engaged the attention of man from the earliest ages and that they appeal palpably to his senses; whilst chemistry and physics are comparatively recent studies, whose aims and processes and even many of their results are understood and appreciated only by the few, though ministering to the welfare of all. Chemistry, in the modern sense of the word, is not a century old; electricity and electro-magnetism are younger still. Mainly by private means, these and cognate branches of science have been advanced in England to their present stage; "but," says Prof. Stokes, "it was perfectly obvious that there were many investigations which it was desirable to carry out and which would require the main part of a man's time; but which involved appliances on so large a scale as to be beyond the power and scope of a private establishment." The plain inference from this pregnant statement is that these desirable investigations cannot be carried on for want of means. It is notorious, indeed, that progress is stayed in many important directions for want of those "appliances and establishments" and that "time" which it is hopeless to expect from private sources.

Still, it may be urged that there is not so much need for these investigations as to demand that the State should undertake them; or, that the help of the State has something noxious about it which tends to paralyse the spirit of philosophical inquiry. Let us examine these two very different objections. The simple answer to the first is given by the very proposal of the deputation. They do not, on their sole representation, weighty though that must be admitted to be, demand that Government physical laboratories shall be established. They say, "We think such things are wanted; but do not take our word for it. Inquire; constitute a commission composed of persons of station, independence and statescraft, to receive our statements and to sift from them our interested enthusiasm, reducing what may be our too soaring aspirations to practical and business-like proportions. Inquire first and then act, if you see fit; but do not persist in neglecting, without inquiry, things that ought to be done."

With regard to the second objection, namely the paralysing effect of State aid, we can only treat it as a purcly sentimental notion. Does Mr. Airy's salary paralyse astronomy? Does Sir Henry James's salary paralyse Geodesy? Does the money spent on art at South Kensington, on pictures for the National Gallery and on collections at the British Museum, paralyse those establishments? Is there something so peculiar in experimental labours as to place them in a category by themselves, subjecting them to malign influences from which the whole of the rest of the business of life is exempt? Are such labours so exceptional in their nature that whilst a public body like the Royal Institution shall purchase apparatus and pay salaries and thus stimulate the genius of Davy, Faraday and Tyndall, the same apparatus and stipends given to them by the State must have reduced these men to torpor?

But to return to practical matters. The main points for a Royal Commission to throw light upon are these. First, is it right that science should be aided at all by the State? Secondly, is the aid now given exactly what is needed-neither too much nor too little? Thirdly, the degree and direction in which science should become a State business having been settled, what will be the best organisation for the purpose? Not one of these points has ever yet been thoroughly considered in England. At present all is arbitrary, inconsistent and incomplete : or, to use Prof. Huxley's comprehensive word, "chaotic." The British Association wishes naturally to reduce chaos to order and they wisely begin - not by definite requisitions for things which few out of their charmed circle know the value of; but by a moderate demand for inquiry. This cannot possibly be refused to them. The nation is thoroughly awakened to a sense of its shortcomings as to education and it will be quite prepared to further those ends to which education is merely a means. The outlay which it will be called upon to provide need not be great; indeed, at first we shall have to deal more with the utilisation of what we already possess, than with the creation of new means. The great point is first to establish a sound principle of working and then to apply it by degrees, with caution and economy.

The word education reminds us of its occurrence in the course of the proceedings before Lord de Grey. Education and Science so naturally associate themselves in the mind that it is hardly possible to discuss the latter as independent of the former. Almost all the great continental scientific endowments include instruction in some form or other. And in this country the greater number of our most distinguished men of science are professors and teachers. The question of scientific instruction must, therefore, necessarily be considered by those who inquire into the question of scientific research. This will be by no means the easiest part of their labour. The complaint now is that men eminently qualified for research have too much of their time occupied in teaching. It will be difficult so to apportion the two functions that they shall reinforce and not obstruct each other. And again, there are some 
departments of science which experience has shown may be safely dissociated from instruction. Astronorny furnishes an example. Mr. Airy would probably not consider that the teaching of a class would aid him much in his peculiar duties.

We have said that this part of the inquiry will be difficult. The whole inquiry is indeed fraught with difficulty. It means nothing less than the constituting of a department of the State of which even the nucleus cannot be said, as yet, to exist. 'To do this liberally and efficiently and yet, with such regard to economy as shall make the result visibly beneficial to the community on whom the cost will fall, will be an achievement worthy of any statesman's ambition; but beyond no real statesman's reach.

We do not doubt that the Commission will be granted. Lord de Grey and Mr. Forster are too experienced to attach undue importance to the apparent want of harmony between some of the opinions expressed, or to suppose that all the grounds on which the Commission was asked for could be given in an hour's conversation. They will rather be swayed by the representative character of those who asked for it.

\section{PETROLEUM AND ITS ALLIES}

CONSIDERABLE anxiety has for some time past prevailed as to the existence of danger attending the use, storage and transport of the mineral oil now used for illuminating purposes and, as the questions involved are not only of great importance in many respects; but likely to be soon brought prominently before the public, some account of the sources of mineral oil and of its characteristics will probabiy be acceptable to our readers.

Thirty years ago, or less, the materials which form the subject of this article were almost unknown to either commerce or manufacturing industry. With some few exceptions, such as the use of the petroleum of Miano, in ltaly, for lighting the streets of Parma and Genoa in 1800 , natural mineral oil was only in scanty demand, under the name of Persian naphtha, for some few minor purposes and it was generally rare, even as a curiosity, in mineralogical collections. The analogous oils obtained artificially, by the distillation of coal and other bituminous materials, were even less familiar; for no material was then known that would yield them in sufficiently abundant proportion to admit of their being manufactured on a commercial scale. For this reason mainly, the various attempts to produce such oil were a succession of failures commercially and it was not until about the year 1840 that Mr. James Young, of Glasgow, had the good fortune to meet with a peculiar bituminous mineral-the precise character of which has been the occasion of much controversy-capable of yielding a very much larger proportion of oil by distillation than any other material of a similar kind. The discovery of this material and the recognition of its oil-yielding capability, were speedily turned to account by Mr. Young and his colleagues, forming the basis of a manufacture that has now assumed gigantic proportions and furnishing a commodity which is, for many thousands of people, a daily necessary.

But scarcely had this paraffin oil, now so well known, begun to come into general use as an illuminating material, than a formidable competitor appeared in the market in the shape of natural mineral oil, derived, at first and for a brief period, from Burmah and subsequently, in overwhelming abundance, from certain districts of North America, chiefly Pennsylvania and Canada. Since the first working of the petroleum deposits of America-about the year 1860 , the exportation of this material, or of products manufactured from it, has increased rapidly and it now amounts to little less than one hundred million gallons a year.

The character of the refined petroleum imported from America has had much infuence in extending its use; for, its pleasing appearance and comparative freedom from disagrecable smell, have gained for it a popular preference that so far is not unfounded.

American petroleum, however, contains a large proportion of à very volatile oil or spirit and, consequently, since the introduction of American refined petroleum into the market, the greater part of the oil derived from that source has been characterised by a greater degree of inflammability than the oil manufactured from Rangoon petroleum and from coal or shale; this difference being due to the fact that the volatile spirit, so abundant in American petroleum, is not completely separated in the process of refining. By leaving this spirit in the refined oil, a larger procluce is obtained by the manufacturer and there is a further advantage gained in this way, owing to the fact that the volatile spirit, when separated, generally sells for only half the price of lamp oil.

The practical question in regard to the safety of mineral oil and its fitness for domestic use, is as to the extent to which the more volatile portions of the crude materials should be separated in the refining operation. Although in reference to this question, the possibility of careless and improper usage of the oil cannot reasonably be regarded as justifying any considerable restrictions in the application of a material so useful; still some allowance requires to be made even for that possibility, taking into account the conditions under which mineral oil is carried, stored and used in a general way. The point to be ascertained is not merely what oil may be used without necessary danger; but what description of oil will best answer the purposes for which it is intended, without requiring a greater degree of caution in its use than can fairly be expected, or any unreasonable restriction on the trade. Hence it would seem to be desirable for the convenience of those engaged in the mineral oil trade, as well as for ensuring public safety, that every branch of this trade should be subject to appropriate regulation: that the degree of inflammability of mineral oil should be limited; a definite standard established and, a mode of testing the oil adopted, which would not admit of discrepant results being obtained, either by accident or otherwise.

With this general object an Act of Parliament "for the Saíe Keeping of Petroleum" was passed in 1862, prohibiting the storage of more than forty gallons of petroleum within fifty yards of a dwelling-house or building in which goods were stored, except in virtue of a license granted by local authorities who had the power to annex to their licenses any conditions thought necessary for diminishing risk of damage by fire or explosion. The application of the term "petroleum" in this Act was specially limited to crude petroleum, or any product of it giving off infammable vapour at a temperature less 